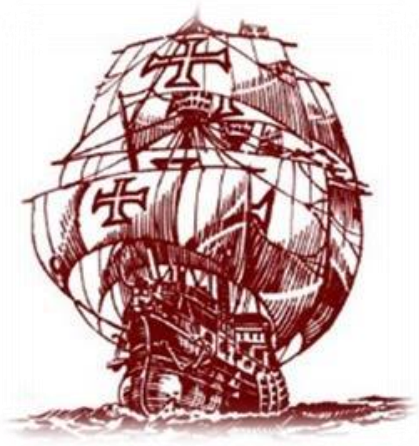

Nau Literária: crítica e teoria de literaturas

www.seer.ufrgs.br/nauliteraria

ISSN 1981-4526 - PPG-LET-UFRGS - Porto Alegre

Vol. 11 N. 02

Literatura e Guerra

\title{
ANTOLOGIA DA MEMÓRIA POÉTICA DA GUERRA COLONIAL ${ }^{1}$
}

Carina Marques Duarte ${ }^{2}$

Entre 1961 e 1974, na tentativa de travar os movimentos independentistas e manter as suas possessões no território africano, Portugal moveu, contra as então colônias Angola, Moçambique e Guiné-Bissau, uma guerra que terminaria somente com a Revolução dos Cravos e o fim do Estado Novo em Portugal. Ao longo dos treze anos de conflito, partiram de Lisboa, tendo como destino a África, barcos carregados de homens e armas, de maneira que, nos três teatros de operações, à medida que aumentavam as frentes de combate, aumentavam também os efetivos portugueses, atingindo o número aproximado de um milhão de soldados mobilizados. Dentre estes, o Estado português contabilizou um significativo número de mortos, feridos, de homens portadores de invalidez permanente e de indivíduos sofrendo de "distúrbios psíquicos de guerra". Os prejuízos humanos, para além dos prejuízos econômicos - já que o conflito absorveu, durante o seu curso, um terço do orçamento nacional - e sociais, conformam a experiência coletiva dos portugueses com a guerra.

O trauma, seja individual ou coletivo, decorrente da participação neste evento bélico, encontrou na poesia um eficiente veículo de expressão. É o que demonstra a Antologia da memória poética da Guerra Colonial, organizada por Margarida Calafate Ribeiro e Roberto Vecchi, na culminância do projeto "Poesia da Guerra Colonial: antologia de um eu estilhaçado", levado a cabo no Centro de Estudos Sociais da Universidade de Coimbra, sob a orientação dos pesquisadores mencionados.

A referida antologia engloba desde textos pertencentes a escritores reconhecidos no panorama literário português, como Manuel Alegre, Fernando Assis Pacheco e José Bação Leal - autores de poesias atinentes à guerra - até autores da cena literária portuguesa -

\footnotetext{
${ }^{1}$ RIBEIRO, Margarida Calafate; VECCHI, Roberto (Org.). Antologia da memória poética da Guerra Colonial. Lisboa: Afrontamento, 2011.

2 Doutora em Literatura Comparada pela Universidade Federal do Rio Grande do Sul. Autora dos livros Do criador de civilização ao eu-abismo: uma leitura palimpsestuosa do Fausto de Fernando Pessoa (2014) e Álvaro de Campos, um seguidor decadente de Whitman e Nietzsche (2017). Atualmente, realiza estudos de pós-doutoramento em Literaturas Africanas de Língua Portuguesa.
} 
como Fiama Hasse Pais Brandão, Luiza Neto Jorge, Maria Teresa Horta, Nuno Júdice, Jorge de Sena, Gastão Cruz, entre outros - que eventualmente dedicaram alguns poemas ao tema, e, por fim, textos de autores não consagrados.

Produzida no momento da experiência direta ou mais tarde, como espaço de elaboração pós-traumática, a poesia da Guerra Colonial não foi obra apenas de indivíduos que estiveram no front. A amplitude e a heterogeneidade do cabedal poético referente à Guerra Colonial - que, aliás, até a iniciativa dos organizadores da Antologia não havia sido sistematizado - como observam Ribeiro e Vecchi, indicam o quanto este - que é sem dúvida um dos acontecimentos mais trágicos e complexos de Portugal - marcou a sociedade portuguesa.

Organizada a partir de imagens-temas, nas quais todo o sujeito histórico se reconhece, a antologia está assim estruturada: Partidas e Regressos, Quotidianos, Morte, Memória da Guerra, Pensar a Guerra, Cancioneiros, e, como tópicos mais específicos desta guerra, Contra a Guerra e A favor da Guerra.

O sofrimento daqueles que partiam rumo à África e dos que permaneciam em Portugal, as despedidas, a ausência de sentido na guerra, as imagens dos barcos e do mar (símbolos da época gloriosa dos Descobrimentos, agora, associadas ao sacrifício da juventude) e a transformação verificada naqueles que retornavam - já que a guerra, lembrando Fernando Assis Pacheco, entra para os ossos e não sai - são algumas das ideias recorrentes em "Partidas e Regressos".

Em "Quotidianos", sobrepõem-se a solidão, o medo, o desespero, as dificuldades da guerra, os combates e as emboscadas. Tais temas reaparecem na seção "Morte", na qual todos os textos se direcionam para o questionamento da morte, seja ela exterior ao homem ou interior. No segundo caso, a escrita surge, para os poetas-soldados, como possibilidade de vida.

O sentimento de que se tratava de uma guerra absurda perpassa as diversas partes da antologia acrescido frequentemente da revolta por ser a pátria a responsável pelas mortes. Some-se a isto a consciência, presente na seção "Guerra a Guerra", de que os soldados são meros instrumentos - o "precioso estrume" -, dos quais Portugal se servia para fazer uma guerra injusta.

Já em "O dever da guerra", o enfrentamento com os horrores da luta armada e o sacrifício de vidas é uma prova de lealdade à pátria. Trata-se aqui de uma escrita legitimadora do conflito, apoiada, muitas vezes, na ideologia da defesa da integridade do Portugal 
imperial ameaçado pelos movimentos independentistas africanos. Em alguns desses textos, a guerra aparece como uma nova Cruzada, e os novos varões assinalados são impulsionados pelos feitos dos ancestrais.

"Pensar a guerra" e "Memória da guerra" são tentativas de pensar a guerra a partir do canto ou dos fragmentos de memória dela resultantes. Os poemas, além de revelarem o intento de exorcizar um trauma e de impor o testemunho do poeta contra o silêncio coletivo, contém um sentimento derrotista, que não é produto apenas da fragilidade de uma consciência individual confrontada com a situação-limite, mas da fragilidade da nação, a qual, baseada em um discurso obsoleto, entregava uma geração à morte. Associando a jornada de África à batalha de Alcácer-Quibir, os poetas demonstram que a Guerra Colonial é uma falsa epopeia.

Os "Cancioneiros", por sua vez, evidenciam o quanto a Guerra Colonial penetrou fundo na cultura portuguesa, indo além do campo literário. Neles se repetem as imagens-temas presentes nas seções anteriores. Cabe ressaltar que os textos tanto se opõem como legitimam o conflito.

Os cancioneiros e os poemas elaboram e rememoram a experiência portuguesa em África, cujos efeitos, apesar do fim da guerra, continuaram sentidos: seja pelas graves dificuldades financeiras que acarretou ao país, seja pelos inúmeros traumas individuais ou pelo trauma coletivo - sentimento de malogro, de fim, de desesperança, somado à consciência dolorosa da nação. Tais efeitos determinam a identidade de Portugal. A Antologia da memória poética da Guerra Colonial - ao trazer uma poesia portadora de uma memória ameaçada -, além de se opor ao esquecimento, contribui, como pretendiam os seus organizadores, para o debate e a memória pública sobre a Guerra Colonial, favorecendo, assim, a reflexão a respeito da identidade do país. 